\title{
Analysis of Public Information Disclosure on the Budget for the Management of Covid-19 Related to the Press and Information Disclosure Law
}

\author{
Nurlis Effendi ${ }^{1}$, Evita Isretno Israhadi ${ }^{2}$ \\ Borobudur University, Faculty of Law, Jakarta, Indonesia ${ }^{1,2}$ \\ \{nurl1155.nur@gmail.com¹, evita_isretno@borobudur.ac.id²
}

\begin{abstract}
Covid-19 is a non-natural disaster that not only charges Indonesia but also many countries in the world. One of the real impacts of this disaster is on the economic sector. Various communities feel the impact of this pandemic. For this reason, the government issues a budget to tackle COVID-19. Escort from the public can be done with the openness of information and the press following the Press Law and information disclosure. For this reason, this study will examine the extent to which public information disclosure carried out by the government is based on the applicable laws and regulations. The research method used is literature review analysis with primary data sourced from various articles and laws and regulations regarding the allocation of funds to tackle COVID-19 in Indonesia. Based on this research, it was found that the government still has not optimally disclosed information to the public regarding the allocation of funds to counter COVID-19.
\end{abstract}

Keywords: Information Disclosure; Press, Law; Budget; Countermeasures; Covid19

\section{Introduction}

Since the discovery of the case of Covid (Corona Virus Disease) 19 in early March 2020 in Indonesia, this pandemic has become more and more widespread in this country. The spread of this disease has entered the local transmission stage. Until the end of July 2020 and towards August there had been at least 106,336 positive cases with 5,058 deaths. This figure shows the massive spread of the Covid-19 virus in Indonesia. 


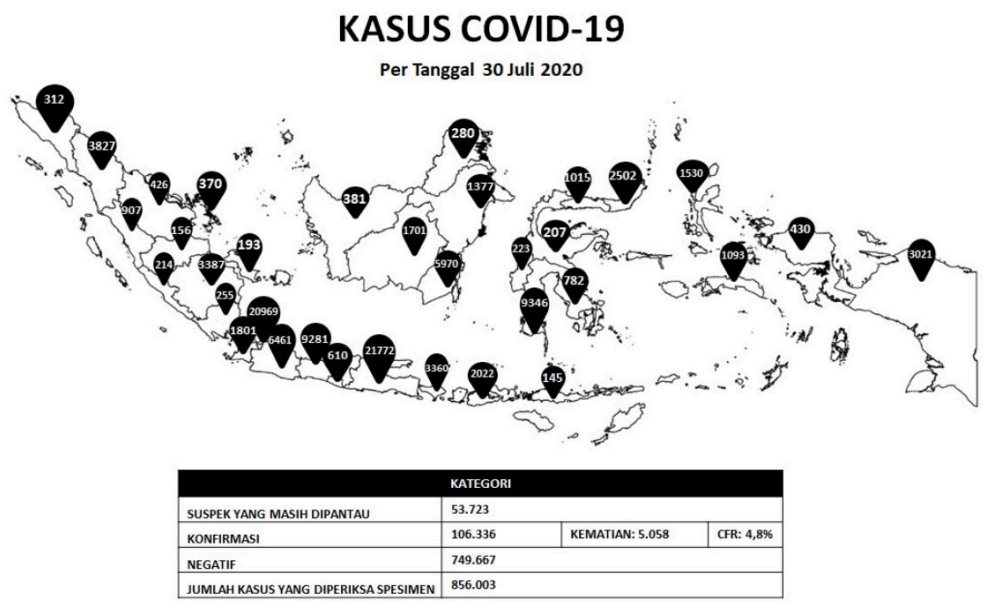

Fig.1. Data on the spread of Covid-19 cases taken from the Indonesian Ministry of Health website

The pandemic which also attacks many countries in the world has had various impacts on various sides of life. Apart from the health aspect with the massive spread of this disease, the real impact that is felt is from a social and economic perspective. The Covid-19 virus pandemic has had a real impact on the world economy. [1] The virus has plunged the world into an economic crisis.

The economic situation in Indonesia has also been affected by this pandemic. The corona 19 pandemic caused an economic contraction, causing income difficulties for people, especially those with low incomes. The effect of this economic situation is due to the limitation of large-scale activities in many places. [2] In his research, Hadiwardoyo found that the economic losses suffered by Indonesia were enormous. There are at least three losses experienced by Indonesia, namely national, sectoral and personal losses. [2] These three disadvantages are closely related to one another. Nationally, Indonesia has suffered losses when various sectors were forced to shut down, such as transportation, tourism and various other sectors that had to stop due to large-scale social restriction (PSBB) policies. On the other hand, national losses also have an impact on personal losses. Each individual also suffers a loss. Like merchants with fewer buyers, online transportation with fewer customers and so on. It is undeniable that the community, especially those with middle- and lower-income earners, are the most affected by this pandemic.

The impact of Covid is very real for micro, small and medium entrepreneurs. In this business, the real impact is not only on the sales of goods but also on the production and distribution. For MSMEs, the production of goods will not be easy with the reduced supply of raw materials for production and the difficulty of human resources when the PSBB is held. The goods produced are also difficult to market, given the decreasing purchasing power of the community. For this reason, short- and long-term policies are needed for MSMEs in dealing with this pandemic. [3] The economic stimulus strategy can stimulate MSME businesses. Given the impact of the Covid-19 pandemic which has attacked almost all sectors, so there is a need for policies that can accommodate all the impacts of this pandemic. 
The government in terms of overcoming the impact of this virus has made many policies, especially those related to the allocation of a fairly large budget (including various types of social assistance). The funds set by the government to tackle the Covid-19 disaster are Rp. 695.2 trillion as reported on the Kompas online. [4] The amount of funds is quite large and fantastic. With this amount of funds, maximum management is needed and can also be monitored so that there is no leakage of funds. For this reason, there is a need for open reporting so that the community can participate in monitoring the allocation of existing funds.

Various policies issued by the government were carried out to deal with the impact of the Covid-19 pandemic. At least as of this writing, there are 29 policies issued by the government, ranging from statutory regulations to press releases regarding the handling of Covid-19. In the policies issued by the government, there are 6 policies that specifically regulate the allocation of funds and also economic activities during the Covid 19 pandemic. These policies are:

a. Government Regulation in Lieu of Law Number 1 Year 2020 Regarding State Financial Policy and Financial System Stability for the Handling of the Corona Virus Disease 2019 (Covid-19) Pandemic and / or in the Framework of Facing Threats Endangering the National Economy and / or Financial System Stability.

b. Presidential Instruction Number 4 of 2020 Concerning Activity Refocusing, Budget Reallocation, and Procurement of Goods and Services in the Context of Accelerating Handling of Corona Virus Disease 2019 (Covid-19).

c. Minister of Finance Regulation Number 23 / PMK.03 / 2020 concerning Incentives for Taxpayers Affected by the Corona Virus Outbreak.

d. OJK Regulation Number: 11 / POJK.03 / 2020 Concerning Economic National Stimulus as a Countercyclical Policy Impact of the Spread of Covid-19

e. Indonesia's Corruption Eradication Commission (KPK) Circular Number 8 of 2020 concerning the Use of the Budget for the Implementation of the Procurement of Goods / Services in the Context of Accelerating the Handling of Corona Virus Disease 2019 (Covid 19) Related to the Prevention of Corruption Crime.

f. Press Release of the Ministry of Economy Number: HM.4.6 / 32 / SET.M. EKON.2.3 / 03/20 20 Regarding the Government Announcing the Second Economic Stimulus to Deal with the Impact of Covid-19.

Looking at the policies issued by the government, especially in terms of allocation of financial funds, transparency of data and information plays an important role in this regard. Financial policy in Indonesia continues to experience growth from time to time. [5] This growth and change should be accompanied by public openness and transparency of information to the existing public. This transparency of public information will benefit both the government and society. In terms of the transparency of the response to covid 19, it needs to be linked to Law 14 of 2008 concerning public information disclosure, so that officials / people who are coping with the corona pandemic understand very well the transparency mandated by law. Because the public or society has the right to obtain information and this right is guaranteed by law. After all, citizens have the human right to get correct and complete information on the response to covid-19 in Indonesia. [6] Because this disclosure of information is a social contract for the welfare of society as well. With this transparency, the public can better understand what really happened about the Covid-19 pandemic. 
Some information regarding the transparency of covid-19 data can indeed be accessed by the public openly. The image below shows some data that can be accessed freely by the public through the Ministry of Health's online page:

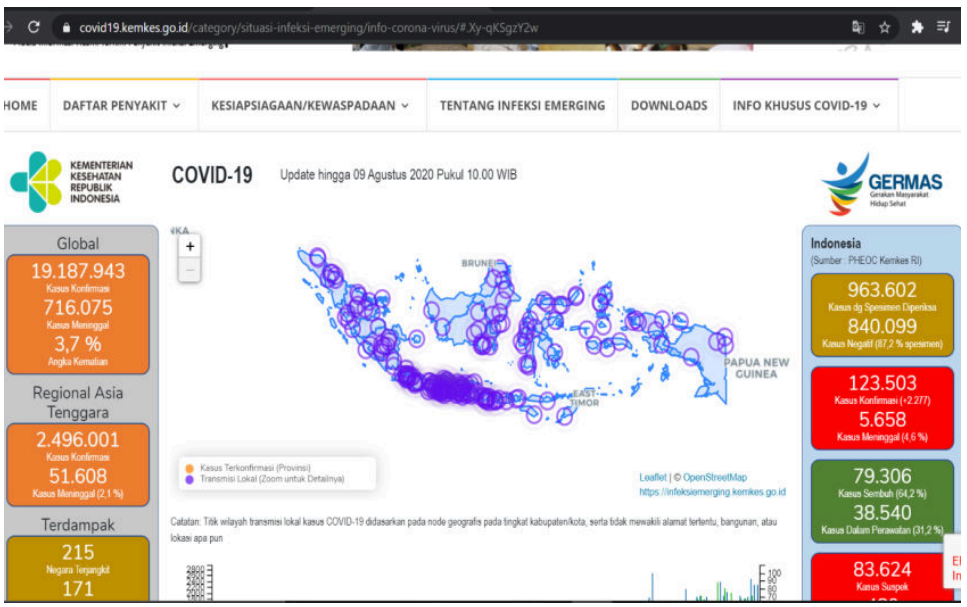

Fig. 2. Display of data on the covid-19 situation in Indonesia on the website of the Indonesian Ministry of Health

Several ministries and local governments provide a recap of the latest information about the development of Covid-19 through their social media pages and web pages. However, not all information can also be accessed openly by anyone. The personal data of Covid-19 patients is one of the data that cannot be spread widely and its confidentiality is guaranteed by the government. [7] This has been regulated by law. This data confidentiality aims to protect the patient concerned from various possible dangers that can reach. However, there are some data that can be disclosed to the public regarding the handling of Covid-19. With some data that can indeed be disclosed to the public, it will be the key to handling the Covid-19 outbreak. [8] However, in fact some of the information circulating is confusing and information about Covid-19 in the central and regional governments is often different, causing confusion in the community. [9]

One of the demands for data openness and transparency regarding Covid-19 is in the field of budget allocation for pandemic handling funds. This refers to the facts in the field regarding the increase in the budget for handling the covid-19 virus which continues to increase but there is minimal open information regarding the absorption of the budget. [10] In an article written by Hidayatullah, it was stated that the cost of handling the outbreak was increased, but in terms of transparency, the absorption was still questionable. In fact, the absorption of these funds has a vulnerability to leak in the middle of the road. This data should be openly accessible so that it can be jointly monitored by the public.

Disclosure of data and information is closely related to the world of the press. It is undeniable that the press world has a role as an information connector. Law No.40 of 1999 states that what is meant by the Press in this law is "a social and mass communication institution that operates within journalistic activities that include seeking, acquire, own, record, analyze, and disseminate 
information, on all forms either in written, sound, picture, sound, and picture, with data and graphic in any other form, by using printing media, electronic media and all kinds of the available channel." However, the problem is whether the data regarding the allocated funds for handling the Covid-19 pandemic is open and widely accessible to the public. In this case, have officials or the Covid-19 response team carried out information disclosure, whether important information is easily accessible to the press world. Looking at the existing situation and conditions, this study aims to conduct a literature review on public information disclosure regarding the covid-19 countermeasures budget related to the public information disclosure law and the press law.

\section{Research Methods}

The research approach used is a qualitative approach. While the method used is literature analysis. This method was chosen in order to provide a real picture of the conditions that occur in the field so that the data presented and the resulting analysis are in harmony. [11] Primary data from this study are various news and policies related to economic data on the handling of Covid19 and various laws and regulations related to press freedom and information disclosure. The data analysis used is an analysis of the literature by comparing the results of existing news with policies and regulations.

\section{Discussion}

The government in overcoming the corona virus has taken a policy by improving health services, providing assistance to small communities, increasing the resilience of the business world. The government has budgeted Rp. 695.2 trillion to anticipate the consequences of the corona virus, and the establishment of a Task Force for the Acceleration of Handling Covid-19, which is one of the tasks to provide information to the Indonesian people regarding the handling of Covid-19. [4] Based on government regulations in lieu of law number 1 of 2020, this budget is taken from the APBN (State Revenue and Expenditure Budget). This large amount of budget is certainly expected to be able to meet the needs of overcoming covid-19. In this Government Regulation in Lieu of Law number 1 of 2020 all policies concerning economic stability are regulated in it. But of course, in practice there is no valid data disclosure related to this policy setting. This is evidenced by the ombudsman's request for data transparency on the handling of covid 19 allocations. [12]

Talking about economic policies for handling covid-19, one of the existing policies is the existence of incentives for taxpayers affected by the covid-19 virus through Minister of Finance Regulation (PMK) number 23 / PMK.03 / 2020. This regulation regulates tax incentives for certain taxpayers to maintain economic stability, stimulate purchasing power and community productivity. This concept is believed to be able to restore economic activity in Indonesia in a situation of the Covid-19 pandemic. This policy provides fresh air not only for the community but

also for entrepreneurs. In many regions, many hotel and restaurant taxes are deferred so that prices can be reduced. Personal income tax is also reduced. This is intended so that the unpaid tax money 
can be a stimulus for lubricating economic wheels. For entrepreneurs they can increase their productivity. For personal taxpayers, they can spend their money to keep the economy running.

Apart from laws and regulations, there is also a policy by the OJK (financial services authority) to regulate the national stimulus as a result of the spread of covid-19. This policy was issued to encourage optimization of banking performance in order to maintain financial system stability and improve the economy. This policy can be included in financial stabilization to maintain the Indonesian economy. [13] With this policy, economic stability will be maintained.

Various stimuli have been disbursed by the government in the context of allocating funds for handling Covid-19. The government also provides assistance to the community in dealing with the impact of Covid 19, including PKH cards, pre-work cards, food cards, exemptions and discounts on electricity rates, social assistance for basic needs. Of course, this large amount of funds spent is an expense that was not planned beforehand. Given the emergency of the existing conditions. These various assistance and allocations were caused by the difficult situation in the existing economic conditions. The difficulty of finding work, selling and various other difficulties due to the impact of covid-19 on the economy. [14] The large allocation and stimulus funds certainly made some people want to know where such large funds had gone. For example, demands from the civil society coalition for an open government so that there is data transparency on the allocation of funds from handling covid-19. [15] Based on this, the transparency of the allocated funds for the acceleration of the Covid budget should be released immediately so that it is known by the public. This data disclosure is in line with laws and regulations regarding information disclosure. As long as the information circulating is not harmful, such as patient data.

With the openness of information, it will bring many benefits for Indonesia. For internal parties, the public will not be confused anymore with the confusion of information. [9] The public will be able to monitor the use of funds to accelerate the handling of covid-19. On the other hand, an evaluation of the use of these funds can also be carried out. As an example of data on BLT distribution, the community could monitor which families needed and which families did not. So that assistance can be right on target. Public information disclosure is closely related to press freedom. Various demands filed for the government to open information as widely as possible regarding the allocation of funds for handling Covid-19 prove that there is still a lot of information that cannot be accessed by the public. Press freedom and information disclosure are things that are needed by the public at this time in relation to the allocation of handling covid-19. This is in line with the laws and regulations that have been decided previously. The public can continue to oversee the allocation of funds for handling covid-19 and reduce the inaccuracy of the existing allocation of funds. However, information disclosure must be accompanied by the responsibility of the press in reporting true and valid news.

\section{Conclusion}

The allocation of funds for the acceleration of the response to covid-19 requires a large amount of funds. For this reason, disclosure of information and involvement of the mass media and the press can reduce the inaccuracy of the existing target allocation of funds. The community can participate in monitoring the use of these funds. However, in fact, based on various studies and opinions, the government still lacks information and data disclosure regarding the allocation of 
funds to tackle covid-19. Even though there are some data that must be kept secret, such as data on covid-19 patients, data regarding the allocation of funds and financial reports can still be published as an accountability by the government to the public. The role of the mass media in reporting existing data will be very crucial. For this reason, social media is asked to remain objective and impartial and to report correct and valid data in accordance with existing facts without the need for frills or irresponsible additions.

\section{References}

[1] M. Burhanuddin, C. I., M. N. U. M., Abdi, and U. M. Makassar, "Ancaman Krisis Ekonomi Global dari Dampak Penyebaran Virus Corona (COVID-19)," AkMen 17, vol. 1, no. 17, pp. 90-98, 2020.

[2] W. Hadiwardoyo, "Kerugian Ekonomi Nasional Akibat Pandemi Covid-19," Baskara J. Bus. Enterpreneursh., vol. 2, no. 2, pp. 83-92, 2020, doi: https://doi.org/10.24853/baskara.2.2.83-92.

[3] A. K. Pakpahan, "Covid-19 Dan Implikasi Bagi Usaha Mikro, Kecil, Dan Menengah," $J$. Ilm. Hub. Int., vol. 1, no. 1, pp. 59-64., 2020, doi: https://doi.org/10.26593/jihi.v0i0.3870.59-64.

[4] D. M. Purnamasari, "Anggaran Penanganan Covid-19 Kini Rp 695,2 Triliun, Ini Penjelasan Wapres," kompas.com, 2020. .

[5] S. Octavianus, "The Cultivation of Indonesia's Education Financing Policy in Disruption Era," Int. J. Adv. Soc. Econ., vol. 1, no. 1, p. 16, 2019, doi: 10.33122/ijase.vli1.36.

[6] T. Michael, "Kesulitan Dalam Memaknai Kesempurnaan Informasi Era Covid-19," Adalah Bul. Huk. dan Keadilan, vol. 4, no. 1, pp. 231-237, 2020.

[7] R. R. Prananda, "Batasan Hukum Keterbukaan Data Medis Pasien Pengidap Covid-19," Law, Dev. Justice Rev., vol. 3, no. 1, pp. 142-168., 2020.

[8] R. Setiawan and E. Komalasari, "Membangun Efektivitas Pembelajaran Sosiologi di Tengah Pandemi COVID-19," EDUSOCIUS J. Ilm. Penelit. Pendidik. dan Sosiol., 2020, doi: 10.1017/CBO9781107415324.004.

[9] M. Fakhruroji, B. Tresnawaty, A. S. H. Sumadiria, E. Risdayah, and K. Kunci, "Strategi Komunikasi Publik Penanganan COVID-19 di Indonesia : Perspektif Sosiologi Komunikasi Massa dan Agama," Ilmu Komun. UIN Sunan Gunung Djati Bandung, vol. 1, no. 1, pp. 1$11,2020$.

[10] T. Hidayatullah, "Transparansi dan serapan anggaran penanganan korona minim," Lokadata.Id., 2020. https://lokadata.id/artikel/transparansi-dan-serapan-anggaranpenanganan-korona-minim (accessed Sep. 24, 2020).

[11] Sugiyono, Memahami Penelitian Kualitatif. Bandung: Alfabeta, 2012.

[12] A. Akbar, "Ombudsman Sulbar Pertanyakan Keterbukaan Penggunaan Anggaran Covid$19, " 2020,2020$. .

[13] H. A. Kurniawansyah, M. Salahuddin, M., and S. Nurhidayati, "Konsep Kebijakan Strategis Dalam Menangani Eksternalitas Ekonomi Dari Covid - 19 Pada Masyarakat Rentan Di Indonesia,” Indones. J. Soc. Sci. Humanit., vol. 1, no. 2, pp. 130-139, 2020. 
[14] S. Hanoatubuan, "Dampak Covid-19 Terhadap Perekonomian Indonesia," EduPsyCouns J. Educ. Psychol. Couns., vol. 2, no. 1, pp. 146-153, 2020.

[15] Koalisi Masyarakat Sipil untuk Pemerintahan Terbuka, "Pemerintah Harus Transparan dalam Pencegahan dan Penanganan COVID-19 di Indonesia," Icel.or.Id., 2020. . 